\title{
Iglesia y orígenes del Estado moderno en la Castilla Trastámara
}

\author{
Jose Manuel Nieto Soria *
}

Al término de la Edad Media predomina en Occidente una determinada forma de estructura política que hoy, en general, se suele considerar como originaria del denominado Estado moderno ¿Hasta qué punto ese Estado moderno vino definido por aportaciones de origen eclesiástico? ¿Hasta qué punto una componente de ese Estado moderno consistió en configurar un cierto tipo de Iglesia?

\section{POLITICA, RELIGIÓN E IGLESIA}

Una característica esencial de la época medieval en su conjunto es la imposibilidad de considerar lo político como un campo autónomo con significación propia por si mismo. Por el contrario, constituye un aspecto bien definitorio del medievo la presencia de unas estrechísimas relaciones entre lo político y lo religioso, siendo resultado de ello el que lo eclesiástico no sea ajeno a lo político.

La más alta instancia de autoridad política, la del monarca, no se sitúa exclusivamente en el terreno de lo laico, sino que, como reconoció Marc Bloch, presenta aspectos que permiten considerarlo en ocasiones como un «quasi-sacerdote». Además, su ideal de referencia viene establecido por Dios mismo como modelo de poder soberano. Así, pues, la

* Profesor Titular de $\mathrm{H}^{a}{ }^{a}$ Medieval. Universidad Complutense. Madrid. 
institución monárquica no puede explicarse al margen de la utilización de un sinnúmero de consideraciones de origen religioso.

Por otra parte, en cuanto que lo religioso actúa como instrumento de comprensión por cada individuo de sus realidades cotidianas, adquiere, como consecuencia, unas posibilidades de valoración política. Así, por ejemplo, lo religioso puede actuar como cauce de comunicación de un mensaje político mediante la utilización del símbolo o de la imagen religiosa. La religión aporta un repertorio de ritos susceptibles de ser empleados en el terreno político. En suma, lo religioso poseerá posibilidades incuestionables en un ámbito tan importante para la política como el de la propaganda y la legitimación.

Finalmente, hay que recordar, por obvio que parezca, que el control de lo religioso está monopolizado por los eclesiásticos, siendo consecuencia de ello que éstos adquieran una significación política específica que se canaliza a través de unas determinadas formas de relación, cambiantes en el tiempo, entre el poder político, en sus diversas manifestaciones, y el poder eclesiástico. Este poder eclesiástico, en cuanto que controlador único de un sistema de creencias aceptado por el conjunto de la sociedad, poseerá una atribución tan esencial políticamente como sacralizar, en unos casos, o convertir en sacrílegas determinadas actitudes políticas.

Todo ello, aunque expuesto muy simplificadamente, pone de manifiesto que nos hallamos, no ante algo puramente accidental, sino ante aspectos esenciales de la estructura antropológica de una civilización.

\section{IGLESIA Y ORIGGENES DEL ESTADO MODERNO EN EL CONTEXTO OCCIDENTAL}

El estudio de las relaciones entre poder político y poder eclesiástico aplicado al período bajomedieval, en especial, si nos referimos a la parte final de dicha época, se incardina de lleno dentro de una temática historiográfica que viene preocupando desde hace varios años a numerosos historiadores, a veces de forma organizada y colectiva a través de amplios y ambiciosos programas de investigación, siendo conocida dicha temática como los orígenes del Estado moderno. La resistencia, en unos casos a aceptar la propia terminología con que se planteaba la cuestión, la disparidad en los enfoques del análisis, la dificultad para establecer criterios ampliamente compartidos para la aproximación a las cuestiones 
más importantes, dio lugar a que, sobre todo en los diez últimos años, hayamos asistido a largos debates en torno a esta temática, debates en cuyo contenido no entraremos aquí.

Hoy día, constituye una interpretación historiográfica ampliamente aceptada en la historiografía occidental el considerar que, entre 1270 y 1360 , tendría lugar una significativa intensificación de la acción de las monarquías en sus diversos ámbitos de competencia (justicia, guerra, fiscalidad...), desarrollándose estrategias políticas diversas, según el contexto propio de cada país, pudiéndose hablar de estrategias pactistas, absolutistas o autoritarias, tal como sucedería en el caso castellano, cuyo resultado sería el surgimiento paulatino de monarquías con unas posibilidades de ejercicio concreto del poder hasta entonces no sospechadas, sin que desde luego, se trate de un proceso lineal y carente de contradicciones, conociéndose tal proceso como orígenes del Estado moderno. En su desarrollo, la relación entre poder político y poder eclesiástico en el ámbito concreto de cada país supondría una línea de transformación esencial, en orden a la configuración de lo que se denomina Estado moderno.

Por contra de las posturas de algunos historiadores para los que no cabe hablar de Estado moderno allí donde persiste una legitimidad politica de origen sagrado, lo que convertiría de hecho en inoperante como concepto de valor histórico a la idea de Estado moderno, dada la larga permanencia hasta tiempos contemporáneos de la legitimación política de origen sagrado en el mundo occidental; habría sido -en opinión de otros autores entre los que me cuento- una característica esencial del Estado moderno surgido al término de la evolución medieval la presencia en el mismo de una fuerte impronta eclesiástica, no pudiéndose considerar, por tanto, el surgimiento del Estado moderno como el resultado de un proceso de laicización de las estructuras políticas, ocurriendo muchas veces justamente todo lo contrario. Todo ello es algo que se da en una dimensión occidental, produciéndose -eso sí- materializaciones específicas y concretas en el ámbito de cada país en función de sus tradiciones propias y de las realidades de cada momento. Es por ello que, antes de entrar en el análisis concreto del caso castellano, imporiaría mucho describir someramente algunos de los rasgos que con aplicación occidental se producen en el transcurso de la denominada génesis del Estado moderno, en cuanto que la consideración de tales rasgos contribuye decisivamente a explicar algunas realidades específicas del caso castellano.

Fue característica esencial de la génesis del Estado moderno - tal como ha observado J. C. Schmitt- la falta de contraposición entre lo sagrado y lo profano, corriendo muchas veces la sacralización paralela a 
la ampliación del poder político centralizado en las diversas realezas, contribuyéndose así al desarrollo de una idea de "Estado soberano", siendo el mismo concepto soberanía de aplicación exclusivamente religiosa hasta una época muy tardía.

Es precisamente en torno a la idea de soberanía cómo se desenvuelven unas relaciones de poder entre Iglesia y Realeza que tendrán una influencia decisiva en la configuración del Estado moderno. Se va a ir desarrollando una conciencia colectiva, según la cual, la soberanía real debe estar por encima de cualquier instancia de poder. La Iglesia de cada reino no puede quedar al margen de dicha soberanía real, el propio papado irá aceptando esta situación y las tradicionales reivindicaciones eclesiásticas en defensa de sus inmunidades y libertades se limitarán a aquellos aspectos en que no entren en colisión con la salvaguarda de esa soberanía real.

Sin embargo, no faltaron reacciones y resistencias en el camino. Junto a la colaboración de notables eclesiásticos en favor de esa soberanía real, aun a renuncia de ciertas cotas de poder, también se dio la confrontación. Así se definieron lo que John A. F. Thomson ha denominado "las esferas de conflicto", de contenidos comunes para las diversas monarquías occidentales. Tales esferas de conflicto afectarán a tres cuestiones: la provisión de beneficios eclesiásticos, la fiscalidad y la jurisdicción. La solución vendrá dada, sobre todo, por vía de negociación entre monarquías y Papado, siendo favorecida esta negociación, como ha estudiado Paolo Prodi, por la renuncia del Pontificado a sus antiguas pretensiones universalistas, al interesarse preferentemente por la construcción de un Estado moderno pontificio para el que aquellas pretensiones universalistas representan sobre todo un lastre. Es durante el siglo XV cuando se desarrolla buena parte de esta negociación, dando como resultados más significativos la disminución de las reservas pontificias, junto con las mayores atribuciones de la realeza en materia de provisión de beneficios eclesiásticos, la sistematización - con el consentimiento pontificio- de la fiscalidad regia sobre los bienes eclesiásticos, la posibilidad de resistencia de los monarcas a los legados pontificios y, finalmente, la cada vez más estrecha colaboración entre la justicia regia y la justicia eclesiástica.

Resultado de todo ello será la institucionalización de lo que podemos entender como Iglesias nacionales, es decir, una Iglesia - la de cada país - cada vez más identificada con el ejercicio de una determinada soberanía real, produciéndose toda una dinámica estatalizadora en la que se pueden advertir, como elementos bien característicos, la integración de lo eclesiástico en el aparato político de cada realeza, dando dimensión 
Iglesia y origenes del Estado moderno en la Castilla Trastámara

eclesiástica a la soberanía regia, y el nuevo concepto de universalidad pontificia que juega a favor de esa dinámica estatalizadora.

\section{EL CASO CASTELLANO: SUS ESPECIFICIDADES CRONOLOGICAS}

La evolución experimentada por la Iglesia castellana con relación al proceso de génesis del Estado moderno que tiene lugar a fines de la Edad Media entra perfectamente dentro de las coordenadas que se acaban de presentar para el conjunto del ámbito occidental. No obstante, ello no impide el que se puedan observar elementos diferenciales que, sin corregir la interpretación global que se acaba de presentar, contribuyen a individualizar cada caso concreto dentro de un contexto general más amplio. En este sentido, conviene, antes que nada, hacer hincapié en las especificidades de la cronología castellana.

Por lo que se refiere a las relaciones entre poder político y poder eclesiástico, las primeras manifestaciones de una cierta dinámica estatalizadora pueden advertirse para el caso castellano en los comienzos de la segunda mitad del siglo XIII, en tiempos de Alfonso X. Es entonces cuando comienzan a definirse claramente unos objetivos de integración de la Iglesia castellana en las estructuras políticas bajo el control de la realeza. Es también entonces cuando se pretende, sin que en muchos casos se llegue a conseguir, una cierta sistematización de formas de intervención del poder político sobre las realidades eclesiásticas, tratándose de un proceso que, sin solución de continuidad, desembocará en la época trastámara. El período comprendido entre la entronización del primer trastámara y el advenimiento de los Reyes Católicos supone, por un lado, la gran época de desarrollo de la vía negociadora entre Papado y realeza a fin de asegurar el predominio de la soberanía real sobre la Iglesia castellana, por otro lado, supone un importante salto cualitativo con respecto a la época anterior, en cuanto que la sistematización del control regio sobre las realidades eclesiásticas alcanza niveles no conocidos hasta entonces. En todos estos rasgos se aprecia una gran unidad cronológica, sin que pueda hablarse de rupturas aparentes, predominando la evolución continuada. La época de los Reyes Católicos significará el correlato lógico de esta evolución previa, al representar la institucionalización plena de prácticas, en parte anómalas, pero aceptadas, propias de épocas anteriores. Es por ello que difícilmente se podría hablar del siglo $x v$ como de una época con significación por sí misma en lo que 
se refiere al problema de las relaciones Iglesia-Estado. Para tal cuestión, el siglo XV habría comenzado ya con los primeros monarcas trastámara y habría terminado en los primeros años del reinado de los Reyes Católicos, allá por la década de los años ochenta.

\section{LAS REALIDADES COTIDIANAS DE LAS RELACIONES IGLESIA- ESTADO EN LA CASTILLA TRASTÁMARA}

Las relaciones Iglesia-Monarquía vienen definidas por todo un conjunto de realidades cotidianas a través de las cuales se define la dimensión eclesiástica de los orígenes del estado moderno, así como la dimensión política de la Iglesia castellana a fines del Medievo. Tales realidades cotidianas afectan a una gran variedad de cuestiones, siendo las más relevantes las siguientes:

1. Los conflictos políticos.

2. La gestión político-administrativa.

3. Privilegización del clero.

4. Fiscalización de las rentas eclesiásticas.

5. Configuración de una Iglesia de Estado.

6. Actividades propagandísticas y legitimadoras.

Importa señalar, antes de entrar en el análisis de estas cuestiones, que los aspectos que interesa desarrollar con respecto a las mismas son aquéllos que nos aportan elementos de reflexión; por un lado, sobre las formas en que la Iglesia castellana contribuyó a configurar el nuevo tipo de estado que se está conformando en, aproximadamente, el último siglo y medio de la Edad Media; por otro lado, en qué forma el poder político contribuyó a definir un cierto tipo de Iglesia acorde con sus objetivos políticos.

\section{Los conflictos politicos}

La Castilla trastámara tiene una de sus características más destacadas en su compleja historia política, la cual viene definida en gran parte por el conflicto nobleza-monarquía. Tal situación de conflictividad y, por 
tanto, de inestabilidad, no se encuentra en contradicción con el desarrollo de un proceso de génesis del Estado moderno en Castilla, sino que, más bien, representa un síntoma de dicho proceso en forma de reacción contraria a su implantación.

La actuación de los eclesiásticos castellanos en el desarrollo de estos numerosos acontecimientos conflictivos casi nunca se produjo en forma de toma de posición conjunta e institucional. En general, la participación eclesiástica en tales conflictos suele tener un carácter individual, no afectando, por tanto, a la globalidad del clero, sino a algunos de sus individuos más encumbrados y más comprometidos políticamente. En estas ocasiones la actitud de buena parte de estos eclesiásticos viene definida por su propia adscripción a un determinado grupo nobiliario o por su propia pertenencia familiar a un linaje concreto. Linajes como los Tenorio, los Luna, los Mendoza o los Carrillo, entre otros, ofrecen buenos ejemplos de ello. En otros casos, la postura de estos eclesiásticos comprometidos se decanta como consecuencia de su larga trayectoria como servidores del poder real, estando, por tanto, más en consonancia con esa dinámica estatalizadora propia de la época. Se trata de eclesiásticos que podríamos calificar, con palabras de Luis Suárez Fernández, de campeones del monarquismo. Un Fernando de Illescas, un Alfonso de Cartagena, un Lope de Barrientos, un Fray Hernando de Talavera o un Cisneros, entre otros, podrían resultar paradigmáticos.

Incluso en los conflictos políticos de mayor calado de la época, aquéllos en que, por la propia dimensión de los hechos, la lglesia se ve implicada de lleno, la lectura de las tomas de postura se hace particularmente compleja. Así sucede, por ejemplo, en la guerra civil que se abre con la deposición en efigie de Enrique IV. A pesar de la intervención pontificia en favor del monarca, prometiendo la excomunión a los que se le opongan, la Iglesia castellana permanecerá dividida, teniendo lugar debates y enfrentamientos en el propio seno de algunas instituciones eclesiásticas tales como cabildos y monasterios. Menos problemático resulta, en cambio, el análisis de la posición eclesiástica adoptada con motivo de la revolución trastámara. Sin llegar a la plena unanimidad, la Iglesia castellana respaldará mayoritariamente al futuro Enrique II, lo que, en cierta manera, contribuirá a hacer comprender el curso tomado por las relaciones Iglesia-Monarquía desde los primeros momentos de la instauración trastamarista.

En suma, la intervención de la iglesia en los conflictos políticos de la época, valorada desde el punto de vista de su capacidad para configurar un determinado tipo de sistema político, sólo excepcionalmente habría 
tenido una importancia realmente significativa, pudiéndosele atribuir un valor más bien secundario en la inmensa mayoría de las ocasiones.

\section{La gestión politico-administrativa}

La participación continuada y más o menos sistemática de clérigos en determinados cargos con responsabilidad política o administrativa directa 0 en otros - no menos importantes - de otro orden, pero con notables posibilidades de influencia política, constituye uno de los aspectos con mayor capacidad configuradora de una determinada forma de gobernar.

Si bien es verdad que a partir de comienzos del reinado de Alfonso XI parece vislumbrarse una cierta profesionalización en el ejercicio de cargos de Corte, lo que Salvador de Moxó denominó la promoción de los letrados, y a pesar de las reiteradas quejas expresadas por los procuradores de las ciudades con motivo de la celebración de reuniones de Cortes, como consecuencia de la presencia de eclesiásticos en el ejercicio de cargos políticos y administrativos, dicha presencia nunca dejó de existir a lo largo de este período, incrementándose en algunos momentos, tanto por su importancia cuantitativa como cualitativa.

El Consejo Real, a partir de su configuración inicial en tiempos de Juan I, garantizó la presencia sistemática y privilegiada de una serie de eclesiásticos en una posición de gran influencia en la gobernación del reino. Cuatro de los doce miembros del Consejo habrian de ser eclesiásticos, preferentemente prelados, debiendo ser ocupada siempre la presidencia del Consejo por uno de eilos. La reforma de esta institución, realizada por los Reyes Católicos, consolidó el carácter eclesiástico de la presidencia. Entre las altas responsabilidades de los presidentes del Consejo Real se hallaban, por ejemplo, la dirección de las deliberaciones en el seno del mismo, la designación de corregidores, la distribución de asuntos a estudiar entre los consejeros, actuando incluso en ocasiones de sustitutos de los monoarcas en la gobernación del reino, como consecuencia de la ausencia del monarca con motivo de su participación, por ejemplo, en actividades militares en la frontera. La pertenencia al Consejo Real fue, además, en no pocas ocasiones, origen del surgimiento de eclesiásticos en funciones de verdaderos privados de algún monarca. A ello debe unirse la pérdida de importancia político-administrativa de las Cortes en favor del Consejo Real. 
Dos de los cargos de la administración central castellana en que se había observado una presencia más significativa y continuada hasta mediados del siglo XIV por parte de eclesiásticos habian sido el de canciller y el de notario. No faltarán ejemplos de dicha presencia durante la época trastámara, sin embargo, disminuirá significativamente con respecto a épocas anteriores, produciéndose una cierta laicización de los mismos. Otros cargos de la administración central, ya de mayor valor administrativo más que político, con frecuente presencia eclesiástica serán los de secretarios, refrendarios y relatores reales. A todos ellos cabe añadir la inexcusable presencia de algún prelado entre los tutores y los preceptores reales en una época en que las minorías de edad jugaron papel tan importante y en que se dio un lugar de primer orden a la educación del príncipe.

Por otro lado, la principal institución sobre la que se apoyaba la justicia real, creación de la época trastamarista, aparte del propio Consejo Real, con competencias también en esta materia, la Audiencia Real, instituida por las Cortes de Toro de 1371, tuvo una fuerte impronta eclesiástica. En un principio, se estableció que contara con siete oidores, de los que tres habrían de ser prelados. Juan I la reformará, estableciendo en ocho el número de oidores y reservando dos de estos puestos para prelados, quienes se alternarian en la presidencia del tribunal. Tal presidencia será ostentada por un prelado hasta 1800 , en que pasará a ser desempeñada por los Capitanes Generales.

Las actividades de embajada y representación de la monarquía castellana ante otras cortes conocieron habitualmente la interverición de algún eclesiástico. En esta materia se podría hablar de una tardía secularización de la gestión de las relaciones exteriores. Las relaciones con el Papado, Francia, Inglaterra y Aragón conocerían con particular intensidad esta participación eclesiástica. A este respecto conviene llamar la atención sobre la importancia que las largas negociaciones que supuso la liquidación del Cisma de Occidente tuvieron de hecho en la formación como embajadores del rey de Castilla de un nutrido grupo de eclesiásticos de sólida preparación universitaria.

Finalmente, no hay que olvidar un cargo de carácter eminentemente eclesiástico, pero de indudable proyección política: el confesor real. El confesor real tenía como misión principal actuar como director de conciencia del monarca, pero ello, inevitablemente, implicaría la expresión de recomendaciones políticas. Por esto, no es de extrañar que algunos confesores reales acaben alcanzando una extraordinaria proyección en la esfera política a partir del ejercicio de sus funciones como tales confesores reales. Fray Fernando de Illescas, Fray Hernando de Talavera o el 
propio Cisneros serán bien representativos de este hecho. Por otro lado, no hay que perder de vista que el confesor real no era un individuo aislado, sino el representante más inmediato ante el rey de una determinada familia eclesiástica. Ello contribuiría a explicar la monopolización de dicho cargo en favor de tres órdenes religiosas: dominicos, franciscanos y jerónimos.

En suma, el estudio de la presencia eclesiástica en la gestión político-administrativa del reino revela una de las claves fundamentales para explicar algunos aspectos significativos de la configuración del sistema político castellano a fines del Medievo. En este sentido, el establecimiento de una prosopografía eclesiástico-política de la época puede resultar particularmente esclarecedora.

\section{Privilegización del clero}

Recibir privilegios y sufrir ciertas formas de fiscalización formaron parte de una misma realidad para un clero cuyas relaciones con la Monarquía, ya desde la más Alta Edad Media, tuvieron en esta doble dimensión uno de sus fundamentos más característicos. El rey era el protector natural de su Iglesia y, como consecuencia de ello, también poseía ciertos derechos de usufructo sobre la misma. La época trastámara, desde esta perspectiva, representará la sistematización institucionalizada de determinadas fórmulas de privilegio y de fiscalización que acabarán teniendo una larga vida, sobreviviendo, en muchos casos, hasta la extinción del Antiguo Régimen en la Península.

Ya, de entrada, la entronización de los Trastámara supuso una cierta clarificación en cuanto a los privilegios de índole fiscal —los más apreciados- del clero, frente a una situación anterior que ofrecía un panorama un tanto caótico. Así, Enrique II estableció que, al igual que los fijosdalgo, los clérigos estarian exentos de pechar en los pedidos regios y señoriales, debiendo hacerlo, en cambio, en los concejiles que estuvieran dirigidos a la realización de obras de interés público, y por las heredades que poseyeran y que estuvieran sujetas a la fiscalidad regia. Tal normativa sería confirmada por los monarcas posteriores.

Pero a estos privilegios de carácter general se añadian aquéllos otorgados a individuos concretos o a comunidades religiosas e instituciones eclesiásticas que afectaban a las cuestiones más diversas. En este sentido, cabe observar cómo la época trastámara supuso ante todo una consolidación de privilegios antes otorgados y que ahora se verán confirmados, revalidándose así al término de la Edad Media para ser conservados 
en muchos casos, sin apenas modificaciones, hasta el término del Antiguo Régimen. Por otra parte, no hay que olvidar en este punto la importante actividad fundadora realizada en aquellos tiempos por iniciativa regia, lo que suponía en cada caso nuevos privilegios, formando parte del proceso de dotación. En este sentido, el volumen documental que da testimonio de ello resulta particularmente abrumador para todos los reinados del siglo XV, pudiéndose acaso destacar el de Juan II.

Otro elemento integrado en los privilegios del clero, el disfrute de abadengos, apenas experimentará amenazas concretas durante este período, si bien se mantendrá una cierta actitud de preocupación por parte de la Monarquía hacia el irrefrenable crecimiento de los mismos. Sin embargo, habrá que esperar a las desamortizaciones del siglo XVi para ver cómo se comenzarán a tomar medidas contundentes en esta materia.

La disponibilidad de una jurisdicción propia bajo el control exclusivo de los tribunales eclesiásticos y definida tanto por razón de los temas de las causas judiciales, como por los límites territoriales, fue uno de los privilegios más tenazmente defendidos por la Iglesia castellana a lo largo de los siglos bajomedievales. Durante el siglo xV, cuando la reivindicación de una soberanía real cada vez más ilimitada se hace particularmente intensa, se irá haciendo progresivamente evidente el interés de la realeza trastámara por conseguir la máxima integración de la justicia eclesiástica en la justicia regia. La presencia de eclesiásticos en los tribunales regios facilitó mucho el camino. También en esta materia se produjo una tendencia por parte del Papado en favor de los intereses de la soberanía real. A ello se unía un cierto sentimiento popular en favor de esta reivindicación regia, expresado a veces con vehemencia. Todo parecía jugar a favor del proceso de integración con el que se pretendía alcanzar un solo rey con una sola justicia. El reinado de los Reyes Católicos representaría un momento de gran aceleración en esta empresa. Antonio Morales Moya hablará de «nacionalización de la Iglesia española». El propio tribunal de la Inquisición, institucionalmente, podría valorarse como una cierta forma de manifestación de este proceso integrador del que se darán nuevos pasos en el transcurso del siglo XVI.

\section{La fiscalización de las rentas eclesiásticas}

La fiscalización regia de las rentas eclesiásticas fue uno de los apartados más significativos, por sus diversas implicaciones, en parte extraeconómicas, de cuantos componían la hacienda regia castellana. Las formas de fiscalización regia sobre la Iglesia no aportan apenas novedades 
con relación a lo que se habia observado hasta la instauración trastámara, apreciándose sobre todo una cierta tendencia a convertir en partidas ordinarias lo que tradicionalmente habia tenido un carácter extraordinario, tal como sucedió, por ejemplo, con las tercias, siendo ésto un resultado más del proceso de negociación entre realeza y Papado y otro ejemplo de la actitud de claudicación de este último. En cualquier caso, décimas, cruzadas, subsidios y tercias seguirán sierido las expresiones más habituales de esta fiscalización regia de las rentas eclesiásticas.

En muchas de las asambleas del clero celebradas en Castilla en el trascurso del siglo XV se testimoniará el rechazo que provoca entre el clero del reino las exacciones fiscales pontificias. En cambio, la expresión de una resistencia hacia las frecuentes tributaciones extraordinarias impuestas continuamente por la Monarquía sobre el clero apenas se rastreará. Así, pues, todo parece indicar que para el clero castellano la fiscalidad regia contaba con una mayor aceptación que la fiscalidad de origen pontificio. Probablemente, el conocimiento por el poder regio de tal actitud favoreciese la imposición de cargas extraordinarias sobre el clero sin contar para ello de la preceptiva autorización pontificia. Tales cargas extraordinarias - verdaderas usurpaciones fiscales en la realidad- fueron particularmente frecuentes en tiempos de Enrique IV y, ya con los Reyes Católicos, se pretendió darles una aparente legalidad al ser presentadas bajo la forma de empréstitos o préstamos. Por esta vía, en 1476 , los monarcas obtendrian una suma de 30.000 .000 de maravedíes, contando para ello con la decidida colaboración de diversos prelados y eclesiásticos, actuando a espaldas de Roma, y cayendo por ello en las correspondientes penas eclesiásticas.

\section{Configuración de una Iglesia de Estado}

Entre las dimensiones que la realeza trastámara pretendió dar al ejercicio de la soberanía real, sobre todo en el trascurso del siglo XV, se cuenta la configuración de una Iglesia que, tanto por las formas de nombramiento de sus jerarquías, como por el desarrollo de instituciones eclesiásticas concretas, como, incluso por las formas de vida religiosa, garantizase una plena sintonía con los objetivos de política eclesiástica pretendidos por la propia realeza. Es por ello, que, entre otras, sobre todo tres cuestiones contribuyen a definir lo que podría calificarse como el intento de configurar una Iglesia de Estado: 
a) Las elecciones episcopales y la provisión de beneficios.

b) La Capilla Real.

c) La política reformadora.

a) Las elecciones episcopales y la provisión de beneficios

El control regio de la Iglesia castellana pasaba necesariamente por la disponibilidad de atribuciones en materia de designaciones eclesiásticas. Ésto, en realidad, excedía de lo propiamente eclesiástico, ya que el poseer tal disponibilidad tenía también importantes implicaciones políticas, si tenemos en cuenta que una de las formas más habituales de compensar los servicios políticos prestados a la realeza por clérigos consistía en la promoción eclesiástica de los mismos.

La intervención regia en las elecciones episcopales contaba con una larga tradición. El proceso canónico establecido para las elecciones, cuando éstas recaían en el capítulo catedralicio, daba entrada en diversos momentos a la intervención regia, ya que el monarca debía recibir notificación de la vacante, nombraba un administrador de los bienes de la mesa episcopal mientras la vacante duraba, daba su consentimiento para que se procediese a la elección, debía dar su «placet» al prelado elegido y proceder a la devolución de los bienes que habían quedado bajo su administración. Así, pues, las posibilidades de influir en el resultado final eran grandes $y$, en la práctica, se utilizaron con este objeto por los monarcas de forma generosa a lo largo de toda la Baja Edad Media. No obstante, la época trastámara y, en particular el siglo xv, aportó novedades importantes en este terreno, novedades, sobre todo, en el sentido de sistematizar de forma plenamente institucionalizada la intervención regia sobre las elecciones. Juan II obtuvo de Martín $\mathrm{V}$ el reconocimiento de que las elecciones episcopales realizadas por los cabildos catedralicios deberian tener en cuenta las preferencias del monarca, considerando que esta práctica ya constituía una costumbre antigua que no debía ser modificada. Enrique IV consiguió de Calixto III la confirmación de este mismo privilegio, a la vez que el pontífice se comprometió a conferir la dignidad episcopal a todo pretendiente indicado por el rey, siendo ésto ratificado más tarde por Pío ll. Los Reyes Católicos obtendrían el derecho de nominación para las más elevadas dignidades de las iglesias y monasterios pertenecientes al patronato real, derecho que Inocencio VIII haría extensivo al reino de Granada y las Canarias, Julio II lo aplicaría también a América y Adriano VI, en 1523, a todo el territorio peninsular. Junto con este derecho de nominación o presentación, los Reyes Católicos obtuvieron el derecho de retención de bulas, con lo que 
quedaba definitivamente configurado lo que sería el patronato real de la época moderna.

La provisión de beneficios eclesiásticos contaba, para los intereses de la Monarquía, con dos vertientes también observables en el caso de las elecciones episcopales. Por un lado, se trataba de que los monarcas dispusieran de la posibilidad de asignar beneficios eclesiásticos a los clérigos que ellos prefirieran; por otro lado, estaba el problema de la obtención de tales beneficios por extranjeros, cosa muy frecuente cuando su provisión se efectuaba por vía de reserva pontificia. Este último aspecto de la cuestión revestía particular gravedad, en cuanto que, desde el punto de vista de los monarcas, amenazaba al ejercicio pleno de la propia soberanía real, al quedar fuera de ella unos individuos extranjeros que, a veces, por su cargo eclesiástico, administraban bienes de particular importancia política o estratégica. Es así que el propio clero castellano respaldó a la monarquía en su reivindicación ante el papado de acabar con la entrega de beneficios a extranjeros, lo que facilitó mucho las negociaciones en esta materia. Junto a la normativa establecida ya por lo menos desde Enrique III, en la que se prohibia a los clérigos acatar a cualquier eclesiástico extranjero, en el trascurso del siglo $x V$ se otorgarían numerosos privilegios pontificios, prometiendo jugar a favor de este nacionalismo beneficial reivindicado por los castellanos y mostrando la buena disposición del Pontificado para las largas listas de eclesiásticos solicitantes de nuevos beneficios remitidas por los monarcas, práctica habitual en esta materia ya desde tiempos anteriores a la instauración trastámara.

\section{b) La Capilla Real}

La formación de una Capilla Real integrada por un importante número de clérigos, los capellanes reales, al servicio directo del rey, de la familia real y de la Corte, parece iniciarse en tiempos de Sancho IV, quien ya dará unas primeras constituciones. A lo largo del siglo XV, a la vez que ampliará el número de sus componentes y competencias, tomará una mayor dimensión eclesiástica y política, siendo reflejo de ello las constituciones dadas para la Capilla Real por Juan II, en 1436, producidas en el marco de una reorganización más amplia del conjunto de los servicios de la Casa y Corte, y por los Reyes Católicos en 1486, continuándose su evolución histórica en la monarquía de Austrias y, Borbones.

La Capilla Real tuvo una importante significación desde el punto de vista de las relaciones entre Monarquía e Iglesia. La práctica totalidad del 
Iglesia y origenes del Estado moderno en la Castilla Trastámara

servicio religioso de la Corte recaía sobre esta institución. Sus miembros más cualificados gozaron generalmente de una importante promoción tanto eclesiástica como política. Finalmente, a través de las constituciones, los monarcas aplicaron sobre la Capilla Real, con carácter experimental, algunas de las fórmulas consideradas como más idóneas para establecer el modelo clerical pretendido en cada caso. Un distinguido capellán y cronista real de Enrique IV, Diego Enríquez del Castillo, aporta datos muy valiosos para apreciar el significado de esta institución:

"Traya señalados varones en su Capilla, así capellanes de grande abtoridad, como cantores de dulces voces, que de contino le descian sus oras cantadas. Estos eran en tanta cantidad, que ningun emperador por monarcha que fuese, podria traer mas abtorizada Capilla: con que sin duda resplandecia la grandeza de su Real estado. Verdad es, que por la mayor parte, unos eran generosos é otros letrados de grande merescimiento; é como fueren tales, de continuo los sublimaba, á unos para obispos, y á otros en grandes dignidades é rentas; por manera que se animaban á le hacer agradables servicios sin enojo. E no solamente aquesto, mas siempre les mandaba hacer mercedes é socorros para sus gastos; de guisa que con aquestos vivian tan ricos como la renta que la Iglesia les daba" (Crónica de Enrique IV, cap. XXII).

\section{c) La política reformadora}

Los monarcas de la dinastía Trastámara consideraron como una competencia que les era propia la actuación en materia de reforma eclesiástica. En efecto, la presencia de una continuada iniciativa reformadora por parte de todos los monarcas trastámaras es algo bien patente para toda esta época, teniendo connotaciones y efectos tardíos que conviene considerar.

Uno de los primeros objetivos de la acción reformadora de los monarcas de la dinastía Trastámara consistió en acabar con la encomendación monástica, tarea iniciada sobre todo por Juan I y continuada a todo lo largo del siglo XV. Con ello, a la vez que se restaba un elemento de poder ostentado tradicionalmente por linajes nobiliarios, puso a muchos monasterios en manos de un control regio sin intermediarios.

Desde que se producen las primeras manifestaciones del denominado movimiento observante, con el que se busca una cierta regeneración en los comportamientos religiosos del clero, a partir del último tercio del siglo XIV, los monarcas van a estar muy directamente implicados en su desarrollo. Algunos de los primeros eremitas más importantes que darán 
impulso inicial al movimiento observante habrían pertenecido al círculo regio. Los monarcas van a intervenir decisivamente en favor de la reforma en los conflictos surgidos en el seno de algunas órdenes religiosas como consecuencia del enfrentamiento entre conventuales y observantes. Buena parte de sus fundaciones estarán condicionadas por vincularse al movimiento observante. Los confesores reales actuarán repetidamente como agentes regios en orden a impulsar el desarrollo de la reforma. Todo ello, favorecerá, además, una cierta imitación de actitudes por parte de la nobleza que también se implicará en este mismo proceso. Pero todo ello también tuvo importantes consecuencias políticas. Una buena parte de algunos de los principales colaboradores de la realeza trastámara en el transcurso del siglo xv salieron de las filas del clero observante. Los jerónimos, como típico exponente del hecho reformador, constituirán una de las órdenes de las que saldrá un número más apreciable de lo que denominamos campeones del monarquismo. Otro tanto cabe apreciar, por ejemplo, con los dominicos y los franciscanos observantes, mientras que las cartujas tomarán frecuentemente el carácter de sedes regias. A ello se añadió el indudable prestigio político-eclesiástico obtenido por los monarcas como consecuencia de su implicación en la empresa reformadora. Nadie discutió ya a los Reyes Católicos el que reformar las órdenes religiosas fuera algo que les atañía muy directamente y así actuaron en consecuencia a través sobre todo de Cisneros. Ya en pleno siglo XVI, la reforma de la Iglesia hispana se consideraba como una competencia consustancial al poder regio y como algo necesario para, en palabras de José Antonio Maravall, asegurar «la politización de la Iglesia española».

\section{Actividades propagandísticas y legitimadoras}

Entre los clérigos que se movían en el entorno real como consecuencia, en la mayoría de los casos, de su participación en la gestión políticoadministrativa del reino, destacaron algunos que bien pueden ser calificados como de "clérigos del rey» que desarrollaron una importante actividad de orden propagandístico y legitimador. Tal actividad vino generalmente definida por su contribución a la elaboración de imágenes del monarca de contenido muy diverso, pero que tuvieron como efecto casi siempre el producir una cierta exaltación de la figura regia, haciéndola, por tanto, más aceptable, o el rodear de una cierta aureola de legitimidad aspectos concretos del ejercicio del poder regio. Así, se podría establecer 
una cierta tipología de imágenes de la realeza de origen eclesiástico y con efecto propagandístico o legitimador:

a) Imágenes retórico-especulativas.

b) Imágenes apologéticas.

c) Imágenes moralizantes.

d) Imágenes rituales.

e) Imágenes iconográficas.

a) Imágenes retórico-especulativas

Fundamentalmente, consisten en elucubraciones de origen teológico que entrarían en el campo de la teología política y que vendrían definidas por la extrapolación de conceptos predicados de la divinidad como poseedora de poder soberano para ser aplicados al rey y al poder regio. Todo ello encontraría su base principal en la creencia, plenamente vigente a fines de la Edad Media, según la cual, el poder real es de origen divino, provocando la consiguiente teologización del oficio divino.

El siglo $\mathrm{XV}$ representará un período en que esta teologización del oficio divino será objeto de mayor profundización. Ello se pone igualmente de manifiesto a través de algunos de los grandes pensadores políticos de la Iglesia castellana (Sánchez de Arévalo, Alonso de Madrigal, Alfonso de Cartagena...), como, muy especialmente, a través de algunos de los cronistas e historiadores de la época, observándose en éstos una particular atención a proveer a la figura regia de una dimensión sacralizadora y mesiánica (Diego Enríquez del Castillo, Andrés Bernáldez, Mártir de Anglería...).

\section{b) Imágenes apologéticas}

Son aquellas destinadas a exaltar la figura del rey como modelo político y personal, atribuyendo al monarca numerosas cualidades resultado de la imaginación del autor o de la exageración de realidades concretas. Generalmente se presentan bajo la forma de textos literarios, sobre todo poéticos, soliendo ser sus autores poetas al servicio de la Corte, entre los que abundan los clérigos, o eclesiásticos pertenecientes a los servicios cortesanos, pero con gran dedicación a la actividad literaria. A veces estas composiciones sobrepasan el marco de difusión que viene dado por la Corte para llegar a un público más amplio. El recurso a lo 
alegórico será frecuente, creando expresiones, y fórmulas de gran valor propagandístico y apologético.

La Corte de Juan II y de los Reyes Católicos serán buenas manifestaciones del florecimiento de este tipo de actividades, tal como ponen de relieve los cancioneros de la época. Bien representativos de una u otra Corte serán Fray Diego de Valencia, Fray Iñigo de Mendoza o Juan del Encina.

c) Imágenes moralizantes

Una de las argumentaciones más repetidas por los clérigos del rey a la hora de ofrecer una imagen del monarca consistió en referirse al rey cristianísimo y al rey virtuoso. La actividad guerrera de los monarcas frente al islam, con riesgo de su propia vida, lo que daba a estos monarcas una cierta aureola de martirio, su devota actitud religiosa personal y su constante acción protectora hacia la Iglesia eran los lugares comunes a los que habitualmente se recurría por los escritores políticos eclesiásticos para justificar la atribución de tales calificativos en favor del monarca. Todo ello alcanzaría su máxima expresión con los Reyes Católicos, tal como lo demuestra la propia oficialización de dicho título de «Reyes Católiccs", obtenido de Alejandro VI por algunos clérigos reales enviados al efecto en 1494, a fin de contrarrestar el título de «roi très chrétien» que venían disfrutando los reyes de Francia desde hacía algunos años.

\section{d) Imágenes rituales}

La casi totalidad de ios principales ritos políticos habitualmente celebrados en Castilla requirió inevitablemente la participación eclesiástica, ofreciendo dichos ritos una indudable imagen de efecto propagandístico y legitimador. Contrariamente a lo que se suele pensar, el rito con implicaciones políticas fue muy frecuente en el reino castellano, si bien presenta formas extraordinariamenie diversificadas y acaso poco sistemáticas. Un repaso a las crónicas de la época pone bien de manifiesto este hecho. Coronaciones, entradas reales, procesiones conmemorativas, misas de significación política, juramentos, homenajes, funerales, bodas, bautizos, destituciones, ajusticiamientos, recepción de embajadas... constituyen ejemplos más que suficientes en los que la presencia eclesiástica otorga una dimensión legitimadora de valor inestimable. 
e) Imágenes iconográficas

La influencia eclesiástica a la hora de ofrecer una imagen de valor propagandístico o legitimador también llegó a la expresión iconográfica. En unos casos, esta influencia eclesiástica se produce actuando como inspiradora de la obra artística, recogiendo ésta la traducción de algunas de las ideas más significativas del pensamiento eclesiástico de orden teológico-político. En otros casos, la influencia se produce de forma más directa, como consecuencia de la intervención de una autoridad eclesiástica como impulsora de una determinada obra artística en cuya realización impone sus gustos concretos. Resultado de todo ello es que buena parte de las principales imágenes de orden literario, especulativo, teológico o moralizante encontrarán su correspondiente traducción en obras artísticas concretas.

Los ejemplos para la época que aquí interesa son bien numerosos. Los panteones reales resultan ser una manifestación privilegiada de todo ello. El panteón de los Reyes Nuevos en Toledo, cuyas obras se realizan siguiendo las instrucciones salidas de la Corte de don Pedro Tenorio y bajo la fiscalización del cabildo catedralicio toledano. La Cartuja de Miraflores, obra de Gil de Siloé, pero que no será ajena a la inspiración del obispo de Palencia don Alonso de Burgos. Los retratos reales de la época destinados a ser ubicados en los templos incidirán sobre la imagen del rey virtuoso, convirtiéndose la figura del rey orante en la fórmula iconográfica más repetida. $O$, finalmente, la iluminación de algunos manuscritos obra de eclesiásticos ofrecerá un buen repertorio de iconografía de indudable valor legitimador, tal como puede apreciarse, por ejemplo, en la Anacephalosis de Alfonso de Cartagena, obispo de Burgos.

Con todo ello, asistiríamos a unos primeros atisbos de lo que acaso podria calificarse como una "imagen de estado", en cuya presentación la influencia eclesiástica habría desarrollado un papel nada desdeñable.

\section{CONCLUSIONES}

Tal como se ha podido ver a partir de las consideraciones precedentes, la configuración del tipo de Estado o, si se prefiere, del sistema político resultante al término de la evolución medieval en Castilla no se puede explicar al margen de la evaluación de los datos aportados por el mantenimiento de unas relaciones continuadas y definidas entre poder regio y poder eclesiástico. Dichas relaciones tendrían como efecto global 
más significativo la mutua interpenetración de la estructura eclesial en la estructura política y de la estructura política en la estructura eclesial. Acaso se podria hablar de una cierta forma de politización o, si se prefiere, de estatalización de la Iglesia castellana y de una «eclesiastización» de la monarquía trastámara, provocando así una mutua aportación a la configuración de la Iglesia hispana de comienzos de la modernidad y del Estado moderno hispánico.

Esta mutua capacidad configuradora, resultante de la continuidad de unas relaciones, tendría una de sus manifestaciones más caracteristicas en la verificación de todo un proceso de transferencia de modelos organizativos, entendiéndose por tal una hipótesis explicativa que, propuesta por Jacques Verger desde una panorámica global occidental, podría ser susceptible de aplicarse al caso castellano. Según dicha hipótesis la configuración del Estado moderno tiene uno de sus fundamentos en la aplicación de modelos políticos, ideológicos, administrativos y personales de origen eclesiástico.

Tal hipótesis parece en principio también aplicable al caso castellano si tenemos en cuenta el material aquí manejado. Desde el punto de vista político, la influencia eclesiástica habría contribuido a la construcción de un sistema monárquico autoritario capaz de concentrar cada vez mayor número de funciones, llevando a cabo una aplicación cada vez más precisa de conceptos de origen eclesiástico, tales como soberanía o sacra majestad, observándose un paralelismo cronológico con las experiencias que en este terreno se están produciendo por parte del Pontificado.

En el plano ideológico parece evidente que las aportaciones del pensamiento proveniente de la teología política jugarían un papel esencial en la definición de los ideales políticos de la época, respondiendo en gran medida a propuestas de índole religiosa y ética, obteniendo por esta vía los monarcas importantes cotas de sacralidad, del mismo modo que los ritos políticos incorporaron las últimas novedades de la liturgia cristiana.

La trasferencia en el modelo administrativo presenta mayores dificultades de seguimiento y apenas se puede - por ahora - ir más allá de las meras hipótesis. Así, parece evidente la aportación eclesiástica a la hora de definir el sistema fiscal castellano de fines del Medievo a través de la incorporación, con carácter ordinario, de tipos fiscales provenientes de la fiscalización de bienes eclesiásticos. Cabría acaso preguntarse por la posible influencia del sistema tributario pontificio sobre el castellano. Por otra parte, la administración eclesiástica se organizó basándose sobre una concepción territorializada del poder en la que la jerarquización del espacio resultaba esencial, frente a unas prácticas administrativas, 
como las regias, tradicionalmente fundadas sobre la relación personal. Da la impresión que la evolución administrativa del Estado moderno hispánico también tendió hacia la aplicación de ese aspecto del moderno administrativo eclesiástico, obteniendo por esa vía una mayor garantía del ejercicio del poder en la globalidad del territorio gobernado. El Derecho Cánonico fue considerado en la Castilla trastámara como derecho supletorio de la legislación regia, lo que unido a la presencia continuada de eclesiásticos en los principales órganos de la justicia real, garantizaría una vía de trasferencia en los comportamientos judiciales entre la justicia eclesiástica y la real, sin olvidar la labor de clérigos comentaristas de los cuerpos legales adscritos al servicio de la Corona.

Finalmente, en el plano de lo personal cabría plantear la existencia de concomitancias entre la reforma en los ideales personales que se observan en el seno de la Iglesia castellana y la paulatina transformación de los ideales personales aplicables al ámbito de los servidores del poder regio, con la elevación de las exigencias profesionales y éticas de los individuos.

En suma, junto a unas realidades palpables, más o menos conocidas, que definen un sistema de relaciones entre Iglesia y Realeza, hoy día, aún son muchas las preguntas sin respuesta, sobre todo, si pretendemos ir más allá de esas realidades palpables para intentar encuadrar en una lógica histórica lo ya sabido. 


\section{INDICACIONES BIBLIOGRÁFICAS}

Sobre el problema de los orígenes del Estado moderno, existe hoy día una extensa bibliografía publicada, la mayor parte de ella, en los últimos años: CLAVERO, Bartolomé, «Institución política y derecho. Acerca del concepto historiográfico de Estado moderno", Revista de Estudios Políticos, núm. 19 (1981), págs. 43-57; del mismo autor, Tantas personas como estados. Por una antropología política de la historia europea, Madrid 1986; Pérez Royo, José, Introducción a la teoría del Estado. BarceIona 1980; Fernández Albadalejo, Pablo, "La transición política y la instauración del absolutismo", en Cien años después de Marx. Ciencia y Marxismo. Madrid 1986, págs. 407-416; DE DıOS, Salustiano, «Sobre la génesis y los caracteres del estado absolutista en Castilla», Studia Historica. Historia Moderna, III (1985), págs. 11-46; LALINDE ABAdíA, Jesús, "Depuración histórica del concepto de Estado", en El Estado español en su dimensión histórica. Barcelona 1984, págs. 17-58; Monsalvo ANTÓN, José María, «Poder político y aparatos de estado en la Castilla bajomedieval. Consideraciones sobre su problemática», Studia Historica. Historia Medieval, IV (1986), págs. 101-167 y LADERo QueSADA, Miguel Ángel, «La genèse de l'Etat dans les royaumes hispaniques médiévaux (12501450)", en Le premier âge de l'Etat en Espagne (1450-1700), Coord. Christian Hermann. París 1989, págs. 9-65.

Son escasas las visiones de conjunto de las que hoy se puede disponer sobre la forma en la que se produjeron las relaciones entre poder político y poder eclesiástico en la Castilla bajomedieval, habiendo sido estudiada más por extenso la época anterior al período trastámara: LINEHAN, Peter, La Iglesia española y el papado en el siglo XIII. Salamanca 1975; NIETO SOP.IA, José Manuel, Las relaciones monarquía-episcopado 
castellano como sistema de poder, 1252-1312, 2 vols. Madrid 1983; del mismo autor, Iglesia y poder real en Castilla. El episcopado (1250-1350). Madrid 1988; ya para una época más tardía, AzCONA DE, Tarsicio, La elección y reforma del episcopado español en tiempos de los Reyes Católicos. Madrid 1960, que, a pesar de su título, dedica algunas páginas a presentar una situación general de las relaciones entre Iglesia y Monarquía durante el conjunto del siglo XV y, sobre todo, durante la época de los Reyes Católicos; Fernández Albadalejo, Pablo, «Iglesia y configuración del poder en la Monarquía Católica», en Etat et Eglise dans la genèse de l'Etat Moderne. Madrid 1986, págs. 209-216 y, más recientemente, NiETo SORIA, José Manuel, «Le controle politique de la vie ecclésiastique en Castille à la fin du Moyen Age (1250-1480)", Razo. Cahiers du Centre d'Etudes Médiévales de Nice, núm. 9 (1989), págs. 89-102 y, del mismo autor, "La configuración eclesiástica de la realeza trastámara en Castilla (1369-1474)", En la España Medieval, núm. 13 (1990), págs. 133-162.

Desde una perspectiva global de Occidente a fines de la Edad Media, interesan para el tema aquí tratado: Thomson, J. A. F., Popes and Princes, 1417-1517. Politics and policy in the Late Medieval Church. Londres 1980; Prodi, Paolo, Il sovrano Pontefice. Bolonia 1982; TILLY, C., The formation of National States in Western Europe. Princeton 1975 y la obra colectiva, coordinada por GENET, J. Ph., y VINCENT, B., Etat et Eglise dans la genèse de l'Etat moderne. Madrid 1986, interesando en ella sobre todo los trabajos de SCHMITT, J. C., «Problèmes religieux de la genèse de l'Etat moderne", págs. 55-63 y VERGER, Jacques, "Le transfert de modèles d'organisation de l'Eglise à l'Etat à la fin du Moyen Age", págs. 31-39.

Por lo que se refiere a las diversas cuestiones que definen de forma concreta las relaciones Iglesia-Monarquía en el trascurso de la época trastámara, la bibliografía resulta más dispersa, ya que son muchas las obras que, sin referirse directamente a las cuestiones aquí planteadas, aportan, sin embargo, abundantes datos de interés. Sobre la conflictividad política de la época trastámara sigue ofreciendo datos y consideraciones importantes el libro de SuÁrez FERNÁNDEZ, Luis, Nobleza y Monarquía. Puntos de vista sobre la historia política castellana del siglo XV. Valladolid 1975, 2. ${ }^{a}$ ed. Asimismo, es muy apreciable el volumen de datos y consideraciones aportadas por ARRANZ GUZMÁN, Ana, "Reconstrucción y verificación de las Cortes Castellano-Leonesas: la participación del clero», En la España Medieval, núm. 13 (1990), págs. 33-132, en que resume la primera parte de su Tesis Doctoral Cortes medievales castellanoleonesas: participación eclesiástica y mentalidades religiosas (Universidad 
de Alcalá de Henares, 1988). Desde el punto de vista de los problemas referidos al sistema institucional en lo que se ve afectado por las relaciones entre Iglesia y Monarquía, pueden verse, por ejemplo: DE DIOS, Salustiano, El Consejo Real de Castilla (1385-1522). Madrid 1982; MARTín Postigo, M. S., Los presidentes de la Real Chancillería de Valladolid. Valladolid 1982; Alonso Getino, Luis, «Dominicos españoles confesores de reyes", La Ciencia Tomista, núm. 14 (1916), págs. 374-451; CASTRO, M., "Confesores franciscanos en la Corte de los Reyes Católicos», Archivo Ibero-Americano, núm. 133 (1974), págs. 55-126; LADERO QUESADA, Miguel Ángel, El siglo xv en Castilla. Fuentes de renta y política fiscal. Barcelona 1982, en especial, las págs. 190 a 212, referidas a la renta eclesiástica en la Castilla del siglo XV; GoÑI GazTAMBIDE, José, Historia de la bula de cruzada en España. Vitoria 1958; SuÁrez Fernández, Luis, Castilla, el cisma y la crisis conciliar (1378-1440). Madrid 1960; DE AzCONA, Tarsicio, «Las asambleas del clero en Castilla en el otoño de la Edad Media», en Miscelánea José Zunzunegui (1911-1974), I, Estudios históricos. I, Vitoria 1975, págs. 203-245; Suberbiola MARTínez, Jesús, Real Patronato de Granada. El arzobispo Talavera, la Iglesia y el Estado moderno (1486-1516). Estudio y documentos. Granada 1985; HeRMANn, Christian, L'Eglise d'Espagne sous le Patronage Royal (1476-1834). Essai d'ecclesiologie politique. Madrid 1988 y NIETO SoriA, José Manuel, "La capilla real castellano-leonesa en el siglo XV: constituciones, nombramientos y quitaciones", Archivos Leoneses, núms. 85-86 (1989), págs. 754. Finalmente, sobre problemas relativos a la dimensión ideológica, propagandística y legitimadora de las relaciones Monarquía-Iglesia pueden verse: MiLHOU, Alain, Colón y su mentalidad mesiánica en el ambiente franciscanista español. Valladolid 1983; del mismo autor "La chauve-souris, le Nouveau David et le Roi caché (trois images de l'empereur des derniers temps dans le monde ibérique: xille-Xvile siècles)", Mélanges de la Casa de Velázquez, XVII (1982), págs. 61-78; BermeJo CABRERO, José Luis, Máximas, principios y símbolos políticos (una aproximación histórica). Madrid 1986; NiETo SoriA, José Manuel, Fundamentos ideológicos del poder real en Castilla (siglos XIII al XVI), Madrid 1988; y del mismo autor, "Apología y propaganda de la realeza en los cancioneros castellanos del siglo XV. Diseño literario de un modelo político», En la España Medieval, núm. 11 (1988), págs. 185-222 y «Les clercs du roi et les origines de l'Etat moderne en Castille: propagande et légitimation (xIIIème-xvème siècles)", Journal of Medieval History (en prensa). 